\title{
Analisis Tingkat Kemampuan Berpikir Kreatif Matematis Siswa SMP Dalam Menyelesaikan Open - Ended Problem Pada Materi Bangun Datar Segi Empat
}

\author{
Pendawi Dwi Herdani ${ }^{1}$, Novisita Ratu ${ }^{2}$ \\ ${ }^{1,2}$ Pendidikan Matematika, Universitas Kristen Satya Wacana, \\ 1202014016@student.uksw.edu, 2 novisita.ratu@staff.uksw.edu
}

INFO ARTIKEL
Riwayat Artikel:
Diterima: 09-02-2018
Disetujui: 01-03-2018

Kata Kunci:

Segiempat

Berpikir kreatif

Open Ended Problem

\section{A. LATAR BELAKANG}

Matematika adalah ilmu yang harus dipelajari pada setiap jenjang pendidikan. Secara umum karakteristik matematika adalah: (1) memiliki objek kajian yang abstrak, (2) mengacu pada kesepakatan, (3) berpola pikir deduktif, (4) konsisten dalam sistemnya, (5) memiliki simbol yang kosong dari arti, (6) memperhatikan semesta pembicaraan. Berdasarkan karakteristik dari matematika, maka dalam mempelajari matematika diperlukan kreatifitas. Kreatifitas memainkan peranan yang penting dalam siklus berpikir matematis tingkat lanjut (Ervync, 1991). Berpikir kreatif merupakan kompetensi tingkat tinggi yang menjadi kelanjutan kompetensi dasar. Akan tetapi tingkat berpikir kreatif matematis siswa di Indonesia masih kurang, salah satunya dapat dilihat dari survei hasil tes dan evaluasi PISA 2015 rata-rata skor pencapaian Matematika Indonesia berada pada peringkat 63 dari 69 negara yang dievaluasi. Peringkat dan rata-rata skor Indonesia tersebut tidak berbeda jauh dengan hasil tes dan survei PISA terdahulu pada tahun 2012 yang juga berada pada kelompok penguasaan materi yang rendah. Oleh karena itu perlu menganalisis tingkat berpikir kreatif matematis siswa.

Kurangnya kemampuan berpikir kreatif juga ditunjukkan oleh beberapa penelitian terdahulu yang mengukur kemampuan berpikir kreatif yang mendukung dengan penelitian ini, seperti halnya penelitian yang dilakukan oleh Arifani (2015) yang menunjukkan bahwa 2,84\% siswa memiliki tingkat 
berpikir kreatif sangat tinggi, 21,49\% memiliki tingkat berpikir kreatif menengah, 29,75\% memiliki tingkat berpikir kreatif rendah, dan 43,80\% memiliki tingkat berpikir kreatif sangat rendah dengan jumlah subjek 121 siswa. Hal ini menunjukkan bahwa tingkat berpikir kreatif matematika siswa masih rendah. Hasil penelitian lain yang dilakukan oleh Septianingrum (2015) menunjukkan bahwa ada 2 siswa berkemampuan matematika tinggi berada pada TKBK 4 dan TKBK 2.2 siswa yang berkemampuan matematika sedang berada pada TKBK 1 (kurang kreatif) dan 2 siswa yang berkemampuan matematika rendah berada pada TKBK 0 .

Hasil penelitian Siswono (2006) bahwa terdapat siswa yang memiliki karakteristik tingkat berpikir kreatif pada tingkat 4, 1 dan 0. Meskipun tidak setiap tingkat terisi, tetapi dengan terisinya tingkat tertinggi (tingkat 4) dan tingkat terendah (tingkat 0), cukup membuktikan bahwa tingkat berpikir kreatif tersebut ada. Berpikir kreatif adalah kemampuan individu untuk memikirkan apa yang telah dipikirkan semua orang, sehingga individu tersebut mampu mengerjakan apa yang belum pernah dikerjakan oleh semua orang (Munandar, 1999: 45). Senada dengan hal itu Maxwell (2004: 136) mengemukakan bahwa berpikir kreatif adalah suatu kemampuan seseorang untuk menciptakan ide atau gagasan baru sehingga membuatnya merasa mampu untuk bisa mencapai berbagi tujuan dalam hidupnya. Dari pendapat diatas dapat disimpulkan bahwa berpikir kreatif adalah kemampuan individu untuk menciptakan ide atau gagasan baru terletak pada inovasi yang membantu diri sendiri untuk mencapai tujuan tertentu.

Kemampuan berpikir kreatif ini menekankan pada beberapa indikator. Siswono (2005) ada tiga indikator berpikir kreatif yaitu kefasihan, fleksibelitas dan kebaruan. Berdasarkan ketiga indikator tersebut, Siswono (2006) mengungkapkan bahwa terdapat 5 tingkataan dari kemampuan berpikir kreatif. Dimulai dari tingkat 4 yang tertinggi sampai tingkat 0 sebagai yang terendah.

Menurut Getzel \& Jackson (Silver, 1997), kreatifitas dalam bidang Matematika dapat diukur dengan pertanyaan open ended yang menyediakan lebih dari satu jawaban. Suherman dkk (2003; 123) mengemukakan problem yang diformulasikan memiliki multi jawaban yang benar disebut problem tak lengkap atau disebut juga Open-ended problem atau soal terbuka. Dengan kata lain, kegiatan kreatif dan pola pikir matematik siswa harus dikembangkan semaksimal mungkin sesuai dengan kemampuan setiap siswa.

\section{B. METODE PENELITIAN}

Jenis penelitian yang dilakukan pada penelitian ini adalah penelitian diskriptif kualitatif yang bertujuan untuk mendeskripsikan tingkat kemampuan berpikir kreatif (TKBK) siswa kelas VIII SMP Negeri 1 Getasan pada materi bangun datar segi empat. Pengambilan subjek penelitian ini menggunakan purposive sampling. Subjek dalam penelitian ini meliputi 6 siswa kelas VIII SMP Negeri 1 Getasan yang diambil berdasarkan hasil ulangan harian yang akan dipilih 2 siswa dengan nilai yang tinggi, 2 siswa dengan nilai yang sedang dan 2 siswa dengan nilai yang rendah. Instrumen tes yang digunakan pada penelitian ini akan disajikan pada tabel 1.

TABEL 1

INSTRUMEN TES KEMAMPUAN BERPIKIR KREATIF

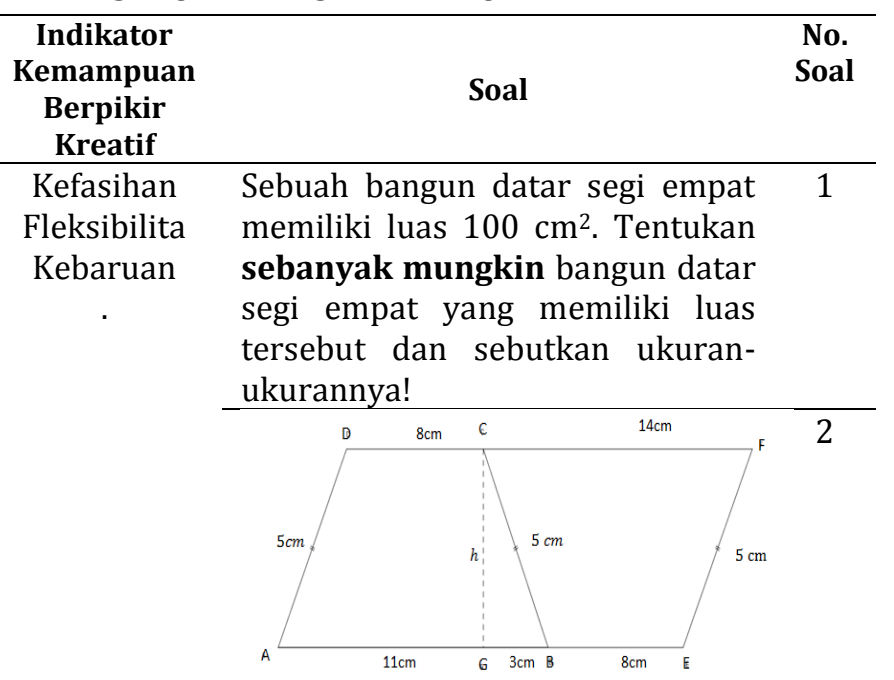

Perhatikan gambar diatas! Jika $\mathrm{AB}=\mathrm{CF}=14 \mathrm{~cm}, \mathrm{BE}=\mathrm{CD}=8 \mathrm{~cm}$, $\mathrm{AD}=\mathrm{BC}=\mathrm{EF}=5 \mathrm{~cm}$ dan $\mathrm{GB}=3 \mathrm{~cm}$, maka tentukan luas bangun tersebut dengan berbagai cara.

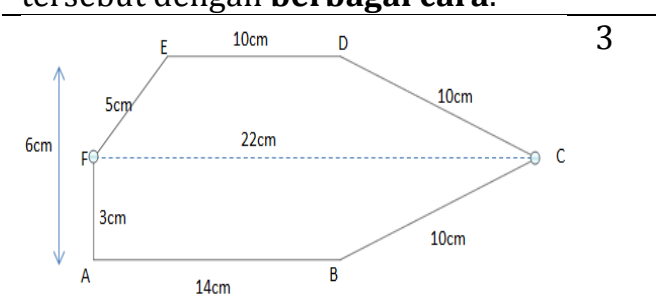

Tentukan luas bangun berikut dengan berbagai cara.

Teknik pengumpulan data dalam penelitian ini adalah teknik triangulasi, yaitu dengan tes 
kemampuan berpikir kreatif, wawancara semi terstruktur dan dokumentasi. Instrumen yang digunakan dalam penelitian ini adalah tes kemampuan berpikir kreatif siswa dengan materi bangun datar segi empat (tipe soal open - ended) dan pedoman wawancara. Instrumen tes yang digunakan dibuat dengan mengacu pada indikator kemampuan berpikir kreatif dari Siswono yang akan disajikan pada tabel 2 .

TABEL 2

DESKRIPSI INDIKATOR KEMAMPUAN BERPIKIR KREATIF

\begin{tabular}{clc}
\hline Indikator & \multicolumn{3}{c}{ Kriteria Kemampuan } \\
\hline Kefasihan & $\begin{array}{l}\text { Siswa mampu menyelesaikan masalah } \\
\text { dengan beragam (lebih dari satu) jawaban } \\
\text { masalah yan bernilai benar. }\end{array}$ \\
\hline Fleksibilitas & $\begin{array}{l}\text { Siswa mampu memecahkan masalah } \\
\text { dengan berbagai cara yang berbeda. }\end{array}$ \\
\hline Kebaruan & $\begin{array}{l}\text { Siswa mampu membuat suatu } \\
\text { penyelesaian yang baru yang belum } \\
\text { pernah dilakukan oleh individu lainnya }\end{array}$ \\
\hline
\end{tabular}

Penelitian ini menggunakan penjenjangan level tingkat berpikir kreatif hasil penelitian yang dilakukan oleh Siswono. Siswono (2011) mengklasifikasikan tingkat kemampuan berpikir kreatif siswa yang terdiri dari lima tingkat yaitu, TKBK 4 (Sangat Kreatif), TKBK 3 (Kreatif), TKBK 2 (Cukup Kreatif), TKBK 1 (Kurang Kreatif), dan TKBK 0 (Tidak Kreatif). Keterangan lebih lengkapnya untuk level Tingkat Kemampuan Berpikir Kreatif (TKBK) hasil penelitian Siswono (2011) dapat dilihat pada tabel 3.

TABEL 3

TINGKAT KEMAMPUAN BERPIKIR KREATIF

\begin{tabular}{|c|c|}
\hline $\begin{array}{l}\text { Level } \\
\text { TKBK }\end{array}$ & Keterangan \\
\hline $\begin{array}{l}\text { Level } 4 \\
\text { (Sangat } \\
\text { Kreatif) }\end{array}$ & $\begin{array}{l}\text { Siswa mampu menunjukkan kefasihan, } \\
\text { fleksibilitas, dan kebaruan atau kebaruan } \\
\text { dan fleksibilitas dalam memecahkan } \\
\text { maupun mengajukan masalah }\end{array}$ \\
\hline $\begin{array}{l}\text { Level } 3 \\
\text { (Kreatif) }\end{array}$ & $\begin{array}{l}\text { Siswa mampu menunjukkan kefasihan } \\
\text { dan kebaruan atau kebaruan dan } \\
\text { kefasihan dalam memecahkan maupun } \\
\text { mengajukan masalah }\end{array}$ \\
\hline $\begin{array}{l}\text { Level } 2 \\
\text { (Cukup } \\
\text { Kreatif) }\end{array}$ & $\begin{array}{l}\text { Siswa mampu menunjukkan fleksibilitas } \\
\text { dalam memecahkan maupun mengajukan } \\
\text { masalah. }\end{array}$ \\
\hline $\begin{array}{l}\text { Level } 1 \\
\text { (Kurang } \\
\text { Kreatif) }\end{array}$ & $\begin{array}{l}\text { Siswa mampu menunjukkan kefasihan } \\
\text { dalam memecahkan maupun mengajukan } \\
\text { masalah. }\end{array}$ \\
\hline $\begin{array}{l}\text { Level } 0 \\
\text { (Tidak } \\
\text { Kreatif) }\end{array}$ & $\begin{array}{l}\text { Siswa tidak mampu menunjukkan ketiga } \\
\text { aspek indikator berpikir kreatif }\end{array}$ \\
\hline
\end{tabular}

Pedoman level tingkat kemampuan berpikir kreatif dapat dilihat pada tabel 4 .
TABEL 4

PEDOMAN LEVEL TKBK BERDASARKAN SISWONO (2008)

\begin{tabular}{cl}
\hline Skor & \multicolumn{1}{c}{ Level } \\
\hline $36 \leq N<45$ & Level 4 (Sangat Kreatif) \\
\hline $27 \leq N<36$ & Level 3 (Kreatif) \\
\hline $18 \leq N<27$ & Level 2(Cukup Kreatif) \\
\hline $9 \leq N<18$ & Level 1(Kurang Kreatif) \\
\hline $0 \leq N<9$ & Level 0 (Tidak Kreatif) \\
\hline
\end{tabular}

Keterangan: $N$ = jumlah skor TKBK

Penelitian ini menggunakan teknik analisis data Miles dan Huberman yaitu reduksi data, penyajian data dan penarikan kesimpulan (Sugiyono, 2012: 338). Analisis data dilakukan dengan menganalisis data hasil tes dan analisis data hasil wawancara. Analisis data hasil tes dilakukan dengan memperhatikan indikator kefasihan, fleksibilitas, dan kebaruan. Analisis dilakukan pada jawaban dan langkah-langkah penyelesaian yang digunakan subjek. Setelah menganalisis hasil tes dilakukan wawancara terhadap 6 subjek terpilih yang mewakili tingkat kemampuan tinggi, sedang dan rendah. Keabsahan data dalam penelitian ini dijamin dengan menggunakan triagulasi metode. Teknik ini dilakukan dengan cara membandingkan hasil wawancara dengan hasil tes yang dikerjakan. Wawancara dilakukan dengan pertanyaan yang sama tetapi dengan instruksi yang lebih mendetail bagi subjek untuk menjawab. Wawancara dilakukan tujuannya untuk mengetahui alasan subjek dalam memberikan jawaban soal tes. Hasil wawancara berupa data kualitatif yang sudah diperiksa keabsahannya kemudian dianalisis dengan langkahlangkah sesuai dengan teknik analisis Miles dan Huberman. Pertama, mereduksi data yaitu dalam hal ini yang dimaksud adalah kegiatan yang mengacu pada proses menajamkan, menggolongkan informasi, dan membuang data mentah yang diperoleh dari lapangan tentang tingkat kemampuan berpikir kreatif siswa dalam menyelesaikan soal yang diberikan kepada subyek. Kedua, penyajian data yaitu meliputi kegiatan mengklasifikasi dan mengidentifikasi data untuk menarik kesimpulan. Penyajian data yang dilakukan dalam penelitian ini adalah pengklasifikasian dan mendeskripsikan berdasarkan tiga kriteria utama berpikir kreatif yaitu kefasihan, fleksibilitas dan kebaruan, siswa dikategorikan pada tingkat kemampuan berpikir kreatif yang terdiri dari lima tingkat, yaitu sangat kreatif, kreatif, cukup kreatif, kurang kreatif, dan tidak kreatif. Terakhir menarik kesimpulan atau 
verfikasi untuk mendeskripsikan tingkat kemampuan berpikir kreatif pada setiap kelompok berdasarkan penyajian data.

\section{HASIL DAN PEMBAHASAN}

Terdapat tiga indikator kemampuan berpikir kreatif menurut Siswono yaitu kefasihan, fleksibilitas, dan kebaruan. Siswono juga mengungkapkan bahwa terdapat 5 tingkat kemampuan berpikir kreatif (TKBK) yaitu TKBK 4 (sangat kreatif), TKBK 3 (kreatif), TKBK 2 (cukup kreatif), TKBK 1 (kurang kreatif) dan TKBK 0 (tidak kreatif). Berdasarkan hasil penelitian menunjukk an bahwa terdapat perbedaan deskripsi dari masing-masing tingkat kemampuan berpikir kreatif pada materi segi empat. Subjek pada tingkat tinggi mampu memperlihatkan beberapa indikator berpikir kreatif sekaligus sedangkan pada tingkat yang lebih rendah subjek belum mampu memperlihatkan indikator kemampuan berpikir kreatif yang ada.

\section{Subjek ANF memiliki Tingkat Kemampuan Berpikir Kreatif 3 (Kreatif)}

Subjek ANF menunjukkan subjek tersebut memiliki TKBK 3 dengan perolehan skor jawaban 29 sesuai dengan kriteria penilaian ketiga indikator TKBK yaitu kefasihan, fleksibilitas dan kebaruan. Soal nomor 1 subjek ANF mampu memberikan 6 jawaban segi empat yang berbeda dengan ukuran yang berbeda, dimana bangun bangun tersebut memiliki luas yang sama yaitu $100 \mathrm{~cm}^{2}$. Hal tersebut mampu menunjukkan dalam kriteria penilaian indikator kefasihan, subjek ANF mendapat skor 5 bukan hanya karena subjek ANF mampu memahami maksud soal namun juga karena mampu memberikan lebih dari satu jawaban dan alasan yang benar dengan pendekatan yang berbeda. Skor yang didapat subjek ANF untuk indikator keluesan adalah 5 karena pada jawaban nomor 1 subjek ANF mampu memberikan jawaban dan alasan benar lebih dari dua pendekatan yang berbeda - beda. Subjek ANF memberikan jawaban dengan cara yang lazim atau biasa digunakan, sehingga skor yang diperoleh subjek ANF untuk indikator kebaruan hanya mendapatkan skor 1 .

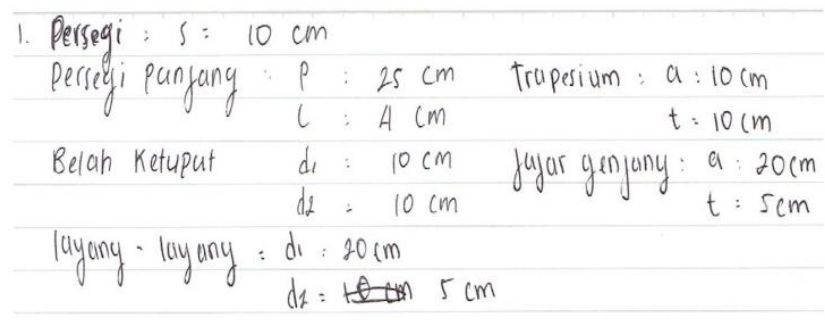

Gambar 1. Jawaban tertulis soal nomor 1 subjek ANF

Jawaban soal nomor 2 subjek ANF hanya memberikan satu jawaban benar, dari hasil wawancara dengan subjek ANF meskipun sebenarnya subjek ANF sudah menjawab dengan cara yang lain dan benar namun karena subjek ANF tidak yakin dengan jawabannya subjek ANF menghapus jawabannya dan jawaban yang terhapus masih terlihat samar - samar pada lembar jawaban subjek ANF. Hal tersebut menunjukakan bahwa subjek ANF mendapat skor 5 pada indikator kefasihan karena subjek ANF sudah memahami maksud soal dan mampu memberikan lebih dari satu jawaban dengan pendekatan yang berbeda. Skor yang didapat subjek ANF untuk indikator keluesan adalah 3 karena subjek ANF mampu memberikan lebih dari satu jawaban dengan pendekatan yang berbeda. Skor yang didapat subjek ANF untuk indikator kebaruan adalah 1 karena subjek ANF menjawab soal tersebut dengan cara yang lazim digunakan.

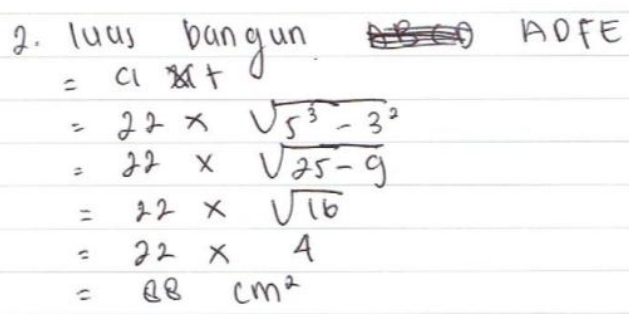

Gambar 2. Jawaban tertulis soal nomor 2 subjek ANF

Jawaban soal nomor 3 hampir sama dengan jawaban soal nomor 2 subjek ANF hanya memberikan satu jawaban benar, dari hasil wawancara dengan subjek ANF meskipun sebenarnya subjek ANF sudah menjawab dengan cara yang lain dan benar namun karena subjek ANF tidak yakin dengan jawabannya subjek ANF menghapus jawabannya dan jawaban yang terhapus masih terlihat samar - samar pada lembar jawaban subjek ANF. Hal tersebut menunjukakan bahwa subjek ANF mendapat skor 5 pada indikator kefasihan karena subjek ANF sudah memahami maksud soal dan mampu 
memberikan lebih dari satu jawaban dengan pendekatan yang berbeda. Skor yang didapat subjek ANF untuk indikator keluesan adalah 3 karena subjek ANF mampu memberikan lebih dari satu jawaban dengan pendekatan yang berbeda. Skor yang didapat subjek ANF untuk indikator kebaruan adalah 1 karena subjek ANF menjawab soal tersebut dengan cara yang lazim digunakan.

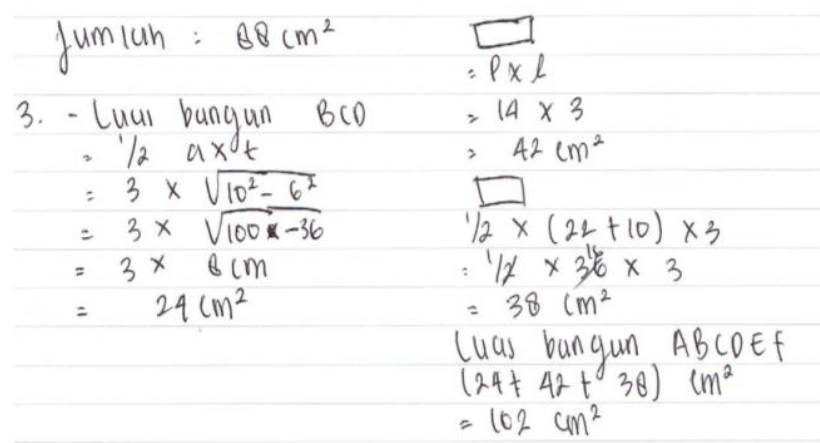

Gambar 3. Jawaban tertulis soal nomor 3 subjek ANF

Dari ketiga soal tersebut total perolehan skor yang didapat subjek ANF sesuai kriteria penilaian ketiga indikator adalah 29, yang menempatkan subjek ANF pada level TKBK 3 (kreatif).

\section{Subjek TL memiliki Tingkat Kemampuan Berpikir Kreatif 2 (Cukup Kreatif)}

Subjek TL menunjukkan subjek tersebut memiliki TKBK 2 dengan perolehan skor jawaban 23 sesuai dengan kriteria penilaian ketiga indikator TKBK yaitu kefasihan, fleksibilitas dan kebaruan. Soal nomor 1 subjek TL mampu memberikan 6 jawaban segi empat yang berbeda dengan ukuran yang berbeda, dimana bangun bangun tersebut memiliki luas yang sama yaitu $100 \mathrm{~cm}^{2}$. Hal tersebut mampu menunjukkan dalam kriteria penilaian indikator kefasihan, subjek TL mendapat skor 5 bukan hanya karena subjek TL mampu memahami maksud soal namun juga karena mampu memberikan lebih dari satu jawaban dan alasan yang benar dengan pendekatan yang berbeda. Skor yang didapat subjek TL untuk indikator keluesan adalah 5 karena pada jawaban nomor 1 subjek TL mampu memberikan lebih dari satu jawaban dan alasan benar dan pendekatan yang berbeda - beda. Subjek TL memberikan jawaban dengan cara yang lazim atau biasa digunakan, sehingga skor yang diperoleh subjek TL untuk indikator kebaruan hanya mendapatkan skor 1 .
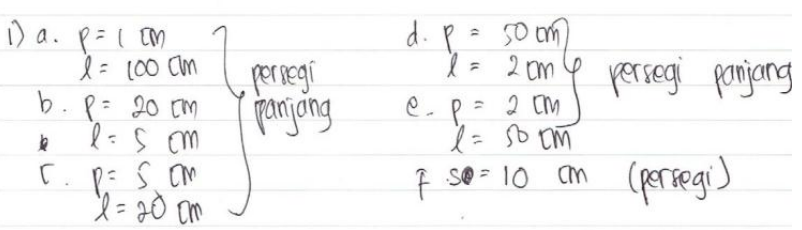

Gambar 4. Jawaban tertulis soal nomor 1 subjek TL

Jawaban soal nomor 2 subjek TL hanya memberikan satu jawaban benar. Hal tersebut menunjukakan bahwa subjek TL mendapat skor 4 pada indikator kefasihan karena subjek TL sudah memahami maksud soal dan memberikan satu jawaban dan alasan yang benar dengan satu pendekatan. Skor yang didapat subjek TL untuk indikator keluesan adalah 1 karena subjek TL mampu memberikan lebih dari satu jawaban dengan satu pendekatan. Skor yang didapat subjek TL untuk indikator kebaruan adalah 1 karena subjek TL menjawab soal tersebut dengan cara yang lazim digunakan.

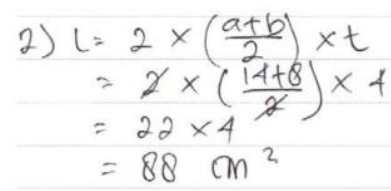

Gambar 5. Jawaban tertulis soal nomor 2 subjek TL

Jawaban soal nomor 3 hampir sama dengan jawaban soal nomor 2 subjek TL hanya memberikan satu jawaban benar. Hal tersebut menunjukkan bahwa subjek TL mendapat skor 4 pada indikator kefasihan karena subjek TL sudah memahami maksud soal dan memberikan satu jawaban dengan satu pendekatan. Skor yang didapat subjek TL untuk indikator keluesan adalah 1 karena subjek TL memberikan satu jawaban dengan satu pendekatan benar. Skor yang didapat subjek TL untuk indikator kebaruan adalah 1 karena subjek TL menjawab soal tersebut dengan cara yang lazim digunakan.

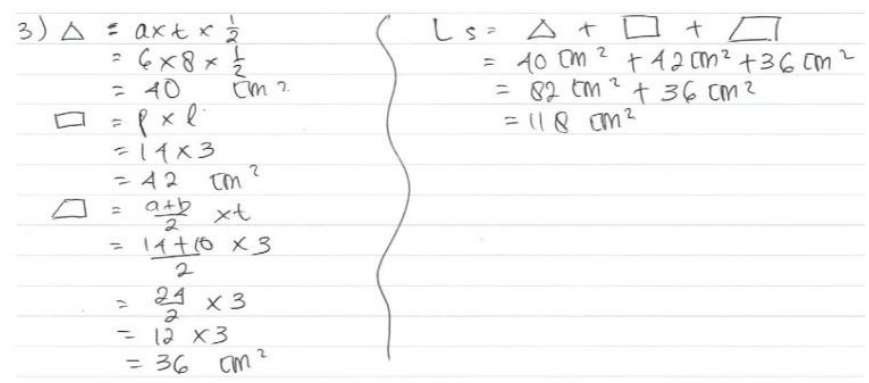

Gambar 6. Jawaban tertulis soal nomor 3 subjek TL

Dari ketiga soal tersebut total perolehan skor yang didapat subjek TL sesuai kriteria penilaian 
ketiga indikator adalah 23, yang menempatkan subjek TL pada level TKBK 2 (cukup kreatif).

\section{Subjek AWA memiliki Tingkat Kemampuan Berpikir Kreatif 2 (Cukup Kreatif)}

Subjek AWA menunjukkan subjek tersebut memiliki TKBK 2 dengan perolehan skor jawaban 23 sesuai dengan kriteria penilaian ketiga indikator TKBK yaitu kefasihan, fleksibilitas dan kebaruan. Soal nomor 1 subjek AWA mampu memberikan 4 jawaban segi empat yang berbeda dengan ukuran yang berbeda, dimana bangun bangun tersebut memiliki luas yang sama yaitu $100 \mathrm{~cm}^{2}$. Hal tersebut mampu menunjukkan dalam kriteria penilaian indikator kefasihan, subjek AWA mendapat skor 5 bukan hanya karena subjek AWA mampu memahami maksud soal namun juga karena mampu memberikan lebih dari satu jawaban dan alasan yang benar dengan pendekatan yang berbeda. Skor yang didapat subjek AWA untuk indikator keluesan adalah 5 karena pada jawaban nomor 1 subjek ABF mampu memberikan jawaban dan alasan benar lebih dari dua pendekatan yang berbeda beda. Subjek AWA memberikan jawaban dengan cara yang lazim atau biasa digunakan, sehingga skor yang diperoleh subjek AWA untuk indikator kebaruan hanya mendapatkan skor 1 .

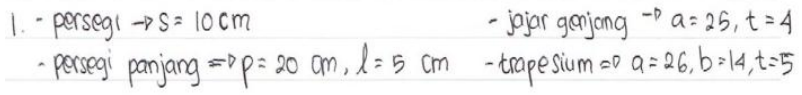

Gambar 7. Jawaban tertulis soal nomor 1 subjek AWA

Jawaban soal nomor 2 subjek AWA hanya memberikan satu jawaban benar. Hal tersebut menunjukkan bahwa subjek AWA mendapat skor 4 pada indikator kefasihan karena subjek AWA sudah memahami maksud soal dan memberikan satu jawaban benar dengan satu pendekatan. Skor yang didapat subjek AWA untuk indikator keluesan adalah 1 karena subjek AWA memberikan satu jawaban dengan satu pendekatan benar. Skor yang didapat subjek AWA untuk indikator kebaruan adalah 1 karena subjek AWA menjawab soal tersebut dengan cara yang lazim digunakan.

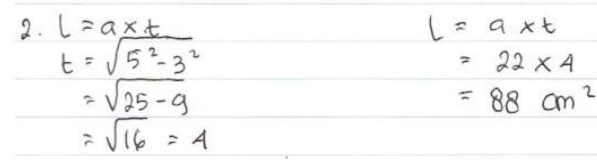

Gambar 8. Jawaban tertulis soal nomor 2 subjek AWA
Jawaban soal nomor 3 hampir sama dengan jawaban soal nomor 2 subjek AWA hanya memberikan satu jawaban benar. Hal tersebut menunjukakan bahwa subjek AWA mendapat skor 4 pada indikator kefasihan karena subjek AWA sudah memahami maksud soal dan memberikan satu jawaban dengan satu pendekatan. Skor yang didapat subjek AWA untuk indikator keluesan adalah 1 karena subjek AWA memberikan satu jawaban dengan satu pendekatan. Skor yang didapat subjek AWA untuk indikator kebaruan adalah 1 karena subjek AWA menjawab soal tersebut dengan cara yang lazim digunakan.

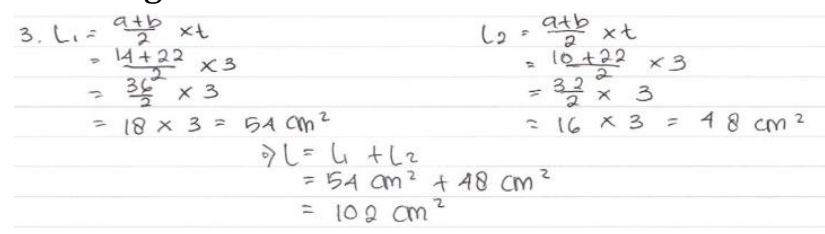

Gambar 9. Jawaban tertulis soal nomor 3 subjek AWA Dari ketiga soal tersebut total perolehan skor yang didapat subjek AWA sesuai kriteria penilaian ketiga indikator adalah 23, yang menempatkan subjek AWA pada level TKBK 2 (cukup kreatif).

\section{Subjek J memiliki Tingkat Kemampuan Berpikir Kreatif 1 (Kurang Kreatif)}

Subjek J menunjukkan subjek tersebut memiliki TKBK 1 dengan perolehan skor jawaban 15 sesuai dengan kriteria penilaian ketiga indikator TKBK yaitu kefasihan, fleksibilitas dan kebaruan. Soal nomor 1 subjek J mampu menyebutkan empat bangun datar segi empat, namun hanya dua bangun yang dapat disebutkan ukuran - ukurannya yaitu persegi dan persegi panjang, hal ini menunjukkan subjek J pada indikator kefasihan mendapat skor 4. Skor yang didapat subjek J untuk indikator keluesan adalah 2 karena pada jawaban nomor 1 subjek J mampu memberikan lebih dari satu jawaban namun ada kekeliruan dalam proses perhitungan. Subjek J memberikan jawaban dengan cara yang lazim atau biasa digunakan, sehingga skor yang diperoleh subjek J untuk indikator kebaruan hanya mendapatkan skor 1 .

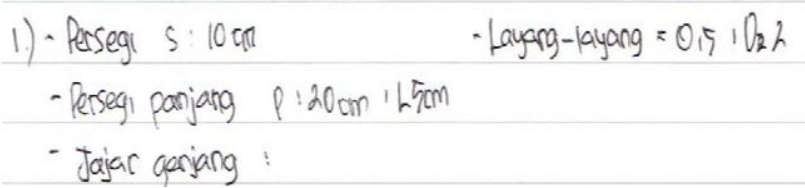

Gambar 10. Jawaban tertulis soal nomor 1 subjek J 
Jawaban soal nomor 2 subjek J hanya memberikan satu jawaban benar. Hal tersebut menunjukkan bahwa subjek J mendapat skor 4 pada indikator kefasihan karena subjek J sudah memahami maksud soal dan memberikan satu jawaban dengan satu pendekatan benar. Skor yang didapat subjek J untuk indikator keluesan adalah 1 karena subjek J memberikan satu jawaban dengan satu pendekatan benar. Skor yang didapat subjek J untuk indikator kebaruan adalah 1 karena subjek J menjawab soal tersebut dengan cara yang lazim digunakan.

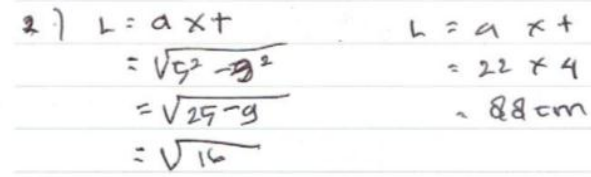

Gambar 11. Jawaban tertulis soal nomor 2 subjek J

Jawaban soal nomor 3 subjek J menjawab dengan satu cara dan hasilnya salah, sehingga pada indikator kefasihan subjek J mendapat skor 2. Skor yang didapat subjek J pada indikator keluesan dan kebaruan adalah 0 karena pada jawaban subjek J memberikan jawaban yang salah.

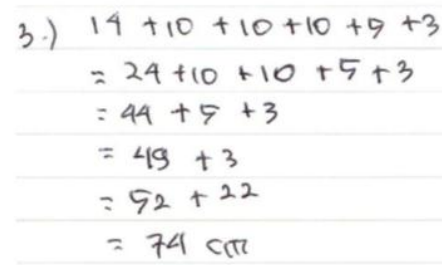

Gambar 12. Jawaban tertulis soal nomor 3 subjek J

Dari ketiga soal tersebut total perolehan skor yang didapat subjek J sesuai kriteria penilaian ketiga indikator adalah 15 , yang menempatkan subjek J pada level TKBK 1 (kurang kreatif).

\section{Subjek AP memiliki Tingkat Kemampuan Berpikir Kreatif 0 (Tidak Kreatif]}

Subjek AP menunjukkan subjek tersebut memiliki TKBK 0 dengan perolehan skor jawaban 4 sesuai dengan kriteria penilaian ketiga indikator TKBK yaitu kefasihan, fleksibilitas dan kebaruan. Soal nomor 1 subjek AP hanya mampu menyebutkan nama - nama bangun segi empat dan tidak bisa menyebutkan ukuran - ukurannya yang memiliki luas $100 \mathrm{~cm}^{2}$. Hal tersebut menunjukkan bahwa subjek AP mampu memahami maksud soal namun memberikan jawaban dengan pendekatan yang salah, skor yang didapat subjek AP pada indikator kefasihan

adalah 2. Skor yang didapat subjek AP pada indikator keluesan dan kebaruan adalah 0 karena pada jawaban subjek AP memberikan jawaban yang salah.

$$
\begin{aligned}
& \text { 1. - Perregi }=5 \times 5=10 \times 4=40 \\
& \text { - Persegi panjang } \\
& \text { - trapesium }
\end{aligned}
$$

Gambar 13. Jawaban tertulis soal nomor 1 subjek AP

Jawaban soal nomor 2 subjek AP tidak bisa menjawab benar sama sekali namun dari hasil wawancara yang dilakukan, subjek AP memahami maksud soal tersebut. Skor yang didapat subjek AP pada indikator kefasihan adalah 1, sedangkan skor pada indikator keluesan dan kebaruan adalah 0 karena pada jawaban subjek AP memberikan jawaban yang salah.

$$
\text { 2. } \begin{aligned}
A B=C f & =14 \mathrm{~cm}+8 \mathrm{~cm}+5 \mathrm{~cm}+3 \mathrm{~cm} \\
& =36 \mathrm{~cm}
\end{aligned}
$$

Gambar 14. Jawaban tertulis soal nomor 2 subjek AP

Jawaban soal nomor 3 subjek AP hampir sama dengan jawaban soal nomor 2, subjek AP tidak bisa menjawab benar sama sekali namun dari hasil wawancara yang dilakukan, subjek AP memahami maksud soal tersebut. Skor yang didapat subjek AP pada indikator kefasihan adalah 1, sedangkan skor pada indikator keluesan dan kebaruan adalah 0 karena pada jawaban subjek AP memberikan jawaban yang salah.

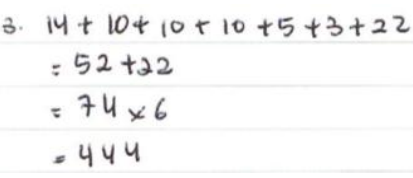

Gambar 15. Jawaban tertulis soal nomor 3 subjek AP

Dari ketiga soal tersebut total perolehan skor yang didapat subjek AP sesuai kriteria penilaian ketiga indikator adalah 4, yang menempatkan subjek AP pada level TKBK 0 (tidak kreatif).

\section{Subjek WSN memiliki Tingkat Kemampuan Berpikir Kreatif 0 (Tidak Kreatif)}

Subjek WSN menunjukkan subjek tersebut memiliki TKBK 0 dengan perolehan skor jawaban 3 sesuai dengan kriteria penilaian ketiga indikator TKBK yaitu kefasihan, fleksibilitas dan kebaruan. Soal nomor 1 subjek WSN tidak mampu memberikan jawaban yang benar, bahkan pada jawaban yang ditulis subjek WSN tidak memuat nama - nama bangun segi empat. Namun hasil wawancara yang dilakukan, subjek 
WSN mampu memahami maksud soal dan mampu menyebutkan bangun datar segi empat. Hal tersebut mampu menunjukkan dalam kriteria penilaian indikator kefasihan, subjek WSN mendapat skor 1 karena hanya mampu memahami maksud soal.

$\begin{array}{ll}1.10 \mathrm{~cm} & 30 \mathrm{~cm} \\ 15 \mathrm{~cm} & 35 \mathrm{~cm} \\ 20 \mathrm{~cm} & 40 \mathrm{~cm} \\ 25 \mathrm{~cm} & 50 \mathrm{~cm}\end{array}$

Gambar 16. Jawaban tertulis soal nomor 1 subjek WSN

Jawaban soal nomor 2 subjek WSN tidak bisa menjawab benar sama sekali namun dari hasil wawancara yang dilakukan, subjek WSN memahami maksud soal tersebut. Skor yang didapat subjek WSN pada indikator kefasihan adalah 1, sedangkan skor pada indikator keluesan dan kebaruan adalah 0 karena pada jawaban subjek WSN memberikan jawaban yang salah.

$$
\text { 2. } \begin{aligned}
L \times P= & 8+14=22 \\
11 & +3+8=32 \\
54 * 25 & =2250
\end{aligned}
$$

Gambar 17. Jawaban tertulis soal nomor 2 subjek WSN

Jawaban soal nomor 3 subjek WSN hampir sama dengan jawaban soal nomor 2, subjek WSN tidak bisa menjawab benar sama sekali namun dari hasil wawancara yang dilakukan, subjek WSN memahami maksud soal tersebut. Skor yang didapat subjek WSN pada indikator kefasihan adalah 1 , sedangkan skor pada indikator keluesan dan kebaruan adalah 0 karena pada jawaban subjek WSN memberikan jawaban yang salah.

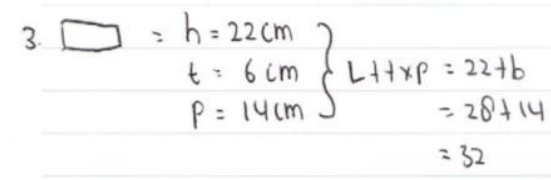

Gambar 18. Jawaban tertulis soal nomor 3 subjek WSN

Dari ketiga soal tersebut total perolehan skor yang didapat subjek WSN sesuai kriteria penilaian ketiga indikator adalah 3, yang menempatkan subjek WSN pada level TKBK 0 (tidak kreatif).

\section{SIMPULAN DAN SARAN}

Berdasarkan analisis dan pembahasan yang telah dilakukan dapat disimpulkan bahwa keenam subjek tersebut memiliki karakter yang berbeda - beda dan tingkat kemampuan berpikir kreatif yan berbeda beda pula. Dari hasil penelitian yang dilakukan di SMP Negeri 1 Getasan menunjukkan bahwa subjek yang memiliki kemampuan tinggi belum tentu menunjukkan bahwa dia kreatif, subjek yang memiliki kemampuan sedang menunjukkan bahwa tingkat kemampuan berpikir kreatif mereka berbeda, subjek yang memiliki kemampuan rendah menunjukkan bahwa keduanya tidak kreatif.

Sebaiknya Guru perlu mempersiapkan diri untuk memberikan perlakuan yang sesuai terhadap siswa dengan memperhatikan tingkat kemampuan berpikir kreatif siswa, sehingga siswa lebih mampu mengembangkan berpikir kreatifnya.

\section{REFERENSI}

[1] Asih, Tabita S. (2015). Kemampuan Berpikir Kreatif pada Materi Segi Empat Siswa Kelas VII H SMP Negeri 2 Klaten. Skripsi. Fakultas Keguruan dan Ilmu Pendidikan Salatiga: Universitas Kristen Satya Wacana.

[2] Chasanah, Fitrotul. (2009). Proses Berpikir Kreatif Siswa Dalam Memecahkan Masalah Terbuka (Open Ended) di Kelas VIII SMP Negeri 35 Surabaya. Surabaya: IAIN Sunan Ampel.

[3] Pratiwi, Rizkia D. (2009). Indentifikasi Proses Berpikir Kreatif Siswa Dalam Pemecahan Masalah Open Ended Creative Problem Solving (CPS). Surabaya: UNESA.

[4] Putri, V. S. P. (2013). Identifikasi Tingkat Kemampuan Berpikir Kreatif (TKBK) Siswa dalam Menyelesaikan Soal Open-Ended pada Materi Segi Empat di Kelas VIII SMP. Jurnal(Online).Tersedia:http://ejournal.unesa.ac.id/in dex.php/mathedunesa/article/view/2708/bacaartikel

[5] Ristiani. (2014). Identifikasi tingkat Berfikir Kreatif Siswa Kelas V SDN Tegalrejo 02 Salatiga dalam Memecahkan Masalah Matematika dengan Tipe Soal Open Ended. Skripsi. Fakultas Keguruan dan Ilmu Pendidikan. Salatiga: Universitas Kristen Satya Wacana

[6] Santoso, Heralius R W. (2015). Deskripsi Tingkat Kemampuan Berpikir Kreatif (TKBK)pada Materi Segi Empat Siswa Kelas VI SMP Negeri 1 Pabelan Kabupaten Semarang. Skripsi. Fakultas Keguruan dan Ilmu Pendidikan. Salatiga: Universitas Kristen Satya Wacana.

[7] Siswono, Tatag Y E. (2006). Implementasi Teori Tentang Tingkat Berpikir Kreatif dalam Matematika. Jurnal(Online).

Tersedia: https://tatagyes.files.wordpress.com/2007/10/tatag_j urnal unej.pdf

[8] Siswono, Tatag Y E. (2007). Desain Tugas untuk Mengidentifikasi Kemampuan Berpikir Kreatif Siswa dalam Matematika. Jurnal (Online). Tersedia: https://tatagyes.files.wordpress.com/2007/10/tatag_j urnal unej.pdf

[9] Sugiyono. (2012). Metode Penelitian Pendidikan Pendekatan Kuantitatif, Kualitatif, dan R\&D. Bandung: Alfabeta. 